\title{
ТУБЕРКУЛЬОЗ ЛЕГЕНЬ У ПАЦІЄНТІВ ПОХИЛОГО ТА СТАРЕЧОГО ВІКУ В ТЕРНОПІЛЬСЬКІЙ ОБЛАСТІ УКРАЇНИ
}

Туберкульоз легень у пацієнтів похилого та старечого віку в Тернопільській області України

\section{л. А. Грищук}

Тернопільський національний медичний університет імені І. Я. Горбачевського МОЗ України

Резюме. Туберкульоз легень у осіб похилого та старечого віку продовжує залишатись актуальною проблемою у фртизіатрії. В пацієнтів такої вікової категорії виникають складнощі у своєчасній діагностиці та лікуванні, які зумовлені несвоєчасним зверненням за медичною допомогою, особливостями вікових змін організму.

Мета дослідження - проаналізувати характер перебігу туберкульозу легень у пацієнтів похилого та старечого віку під час стаціонарного лікування.

Матеріали і методи. У клінічному дослідженні взяли участь 152 хворих на туберкульоз легень, які лікувались у Тернопільському обласному протитуберкульозному диспансері. Клінічний діагноз був виставлений на основі клінічних, лабораторних та рентгенологічних досліджень. Ефеектиність лікування оцінювалась на момент виписки зі стаціонару. Пацієнтів поділили на дві групи: 104 особи похило віку (перша група) та 48 осіб старечого віку (друга група).

Результати. При аналізі характеристики хворих на туберкульоз похилого та старечого віку встановлено, що серед них переважали жителі сільської місцевості: особи похилого віку - 62,0 \%, старечого віку - 79,2 \%. За типом туберкульозного процесу - вперше діагностовано було серед осіб похилого віку - 90,4 \%, старечого віку - 95,8 \%. При госпіталізації у пацієнтів похилого віку деструкція легеневої тканини спостерігалась у 42,3 \%, старечого віку - в 54,2 \%. Наявність мікобактерій туберкульозу в мокротинні виявлено серед осіб похилого віку в 59,6 \%, осіб старечого віку - у 70,8 \%. Лікувались ефрективно 75,0 \% пацієнтів похилого віку $і$ 68,8 \% старечого віку.

Висновки. 3 метою своєчасного виявлення туберкульозу легень у осіб похилого та старечого віку необхідно покращити методи діагностики цього захворювання в пацієнтів старше 60 років, зокрема жителів сільської місцевості. Необхідно розширити можливості комплексного лікування за рахунок нових протитуберкульозних препаратів.

Ключові слова: туберкульоз легень; хворі похилого та старечого віку; діагностика; лікування.
Pulmonary tuberculosis in patients of elderly and senile age in the Ternopil region of Ukraine

\section{A. Hryshchuk}

I. Horbachevsky Ternopil National Medical University e-mail: gryshchuk@tdmu.edu.ua

Summary. Pulmonary tuberculosis in the elderly and senile continues to be a pressing problem of tuberculosis. Patients of this age category have difficulties in timely diagnosis and treatment, which are due to late seeking medical help, features of age-related changes in the body.

The aim of the study - to analyze the nature of pulmonary tuberculosis in elderly and senile patients during inpatient treatment.

Materials and Methods. The clinical study involved 152 patients with pulmonary tuberculosis who were treated at the Ternopil Regional TB Dispensary. The clinical diagnosis was made on the basis of clinical, laboratory and radiological examinations. The effectiveness of treatment was assessed at the time of discharge from the hospital. Patients were divided into two groups: 104 elderly people (group I) and 48 senile people (group II).

Results. When analyzing the characteristics of patients with tuberculosis of the elderly and senile, it was found that among them the predominant residents of rural areas: the elderly $-62.0 \%$, senile - $79.2 \%$. By type of tuberculosis process $-90.4 \%$ of elderly people and $95.8 \%$ of senile people were diagnosed for the first time. Upon admission to the hospital in elderly patients, destruction of lung tissue was observed in $42.3 \%$, senile - in $54.2 \%$. The presence of Mycobacterium tuberculosis in sputum was detected among the elderly in $59.6 \%$, the senile - in $70.8 \% .75 .0 \%$ of elderly patients and $68.8 \%$ of senile people were treated effectively.

Conclusions. In order to timely detect pulmonary tuberculosis in the elderly and senile, it is necessary to improve the methods of diagnosis of this disease in persons older than 60 years, including rural residents. It is necessary to expand the possibilities of complex treatment due to new anti-tuberculosis drugs.

Key words: pulmonary tuberculosis; elderly and senile patients; diagnosis; treatment. 


\section{ВСТУП}

Туберкульоз (ТБ) залишається однією 3 глобальних проблем охорони здоров'я як в Україні, так і в усьому світі. Щороку від туберкульозу помирає понад 1,5 млн людей в усьому світі (4000 осіб в Україні). Україна належить до лідерів у Європі за рівнем захворюваності на туберкульоз, особливо на мультирезистентний. У 2019 р. в країні було зареєстровано 25,2 тис. нових випадків, а всього на обліку перебувало майже 30 тис. хворих. При тому, що за даними ВОО3, близько 23 \% випадків захворювання в Україні не визначаються.

ТБ $є$ однією із 10 головних причин смерті у світі й головною причиною смерті від одного певного збудника інфекції (більше ніж ВІЛ/СНІД). Епідеміологічна ситуація 3 туберкульозу в Україні залишається складною та на сьогодні має певні особливості, а прогноз щодо її подолання найближчим часом $€$ досить сумнівним. За даними національних та міжнародних експертів головними причинами епідемічно напруженої ситуації $€$ низьке виявлення і невідповідне лікування хіміорезистентних випадків ТБ [1, 2].

Останніми роками в багатьох країнах (особливо економічно розвинених) спостерігається зростання серед населення питомої ваги осіб похилого і старечого віку. Збільшується їх кількість і в Україні. Це призводить до відносного підвищення показників захворюваності, хворобливості й смертності від туберкульозу в цих вікових групах. Крім продовження тривалості життя населення, причиною зростання туберкульозу є також зниження імунітету в старших осіб, несвоєчасна діагностика захворювання (люди похилого віку іноді роками, навіть десятиріччями не проходять профрілактичну фрлюорографію) і відносно низька ефективність лікування, що призводить до хронізації процесів. Необхідно пам'ятати про значну епідеміологічну небезпеку нерозпізнаного туберкульозу з бактеріовиділенням в осіб похилого віку, які часто доглядають дітей. Захворюваність осіб, які контактують із бактеріовиділювачами похилого віку, в 8 разів перевищує захворюваність тих, що мають контакт із хворими молодшого віку [3].

Питання постаріння населення надзвичайно актуальне для України, попри незначну середню очікувану тривалість життя. Україна входить у групу країн, де тривалість життя становить 65-70 років. За цим показником (67,9 року) вона посідає 123-є місце в світі. Згідно 3 класифікацією періодів старіння, похилим вважається вік 61-71 для чоловіків, 56-74 для жінок, старечим - 71-90 для чоловіків, 74-90 для жінок, довгожителями - 90 і більше років. Загалом клінічні вияви туберкульозу в осіб похилого та старечого віку бувають досить яскраво вираженими, та не мають якихось специфрічних особливостей, порівняно з ознаками захворювання, що розвивається в молодому віці. Рентгенологічні зміни при туберкульозі легенів у хворих похилого та старечого віку, на думку більшості авторів, вирізняються значною поширеністю та частотою атипової (у тому числі нижньочасткової) локалізації. Порожнини розпаду виявляють у 53-82,4 \% таких. У хворих похилого та старечого віку туберкульозний процес перебігає на тлі вікових змін імунної системи, які, очевидно, змінюють характер імунної відповіді на мікобактерії. Розвиток туберкульозу сам по собі також приводить до активізації механізмів самообмеження імунної відповіді. Отже, активний туберкульоз і старіння виявляють односпрямований вплив, пригнічуючи здатність організму фрормулювати імунну відповідь $[4,5]$.

Автори вважають, що в останні роки спостерігається «постаріння» туберкульозу, тобто підвищення питомої ваги хворих похилого та старечого віку в загальній структурі захворюваності на туберкульоз, а епідеміологічна небезпека цієї вікової групи залишається високою, особливо для дітей. У осіб похилого та старечого віку складнощі діагностики туберкульозу зумовлені малосимптомним перебігом захворювання, нашаровується симптоматика супутніх захворювань, яка маскує клінічні вияви туберкульозу. Найчастіше такими супутніми захворюваннями є неспецифічні ураження легень, патологія серцево-судинної системи, органів травлення та інші порушення, що стають супутниками старості. У більшості хворих на туберкульоз людей похилого та старечого віку виявляють різні супутні захворювання, серед яких переважають ішемічна хвороба серця (IXC) (65\%), артеріальна гіпертензія (50\%), хронічний бронхіт (50\%), атеросклероз центральних і периферичних артерій (35 \%), захворювання печінки $(26,8$ \%) $[6,7]$.

Вікові чинники не тільки збільшують ризик реактивації туберкульозу, але й підвищують сприйнятливість до туберкульозної інорекції, спричиняючи спалахи, наприклад у будинках перестарілих. Для оптимізації медичних послуг та боротьби з туберкульозом у цій підгрупі необхідні детальні знання про епідеміологічні особливості туберкульозу в людей похилого віку [8].

Легеневий туберкульоз залишається діагностичним викликом, особливо в умовах низьких ендемічних ситуацій зі старінням населення. За останні 20 років було досягнуто прогресу в спробах удосконалити діагностику туберкульозу. Однак міжнародні рекомендації щодо дослідження все ще значною мірою покладаються на показник підозри, візуалізації та в кінцевому рахунку культивування Мусobacterium tuberculosis, який залишається золотим стандартом діагностики захворювань на туберкульоз. Останніми досягненнями $€$ молекулярна діагностика зі здатністю швидко ідентифікувати захворювання на туберкульоз та 
резистентність до лікарських засобів та послідовність цілого генома. Досліджено обґрунтованість діагностики туберкульозу в людей похилого віку, щоб допомогти практичному лікареві в діагностиці у цій популяції [9].

Автори провели ретроспективне когортне дослідження, в якому порівняно клінічні, рентгенологічні та демограсрічні характеристики пацієнтів із туберкульозом у віці $\geq 65$ років і хворими на туберкульоз у віці 18-64 роки у Великобританії. Встановлено, що задишка була частішою серед пацієнтів старшого віку $(p=0,001)$. Час від надання медичної допомоги до початку лікування у молодших був коротшим порівняно зі старшими пацієнтами: 3 проти 15 днів ( $p=0,001)$. Отже, у пацієнтів старшого віку $\geq 65$ років із туберкульозом було менше «класичних» клінічних та рентгенологічних захворювань на туберкульоз, що може пояснити більш тривалий час початку лікування від появи симптомів порівняно 3 молодшими пацієнтами у віці <65 років [10].

Метою дослідження було проаналізувати характер перебігу туберкульозу легень у пацієнтів похилого та старечого віку під час стаціонарного лікування.

\section{МАТЕРІАЛИ I МЕТОДИ}

У клінічному дослідженні взяли участь 152 хворих на туберкульоз легень, які лікувались у Тернопільському обласному протитуберкульозному диспансері. Клінічний діагноз було виставлено на основі клінічних, лабораторних та рентгенологіч- них досліджень. Ефективність лікування оцінювалась на момент виписки зі стаціонару. Пацієнтів поділили на дві групи: 104 особи похило віку (перша група) та 48 осіб старечого віку (друга група), проведено аналіз залежно від статі пацієнтів. Були проаналізовані такі критерії, як: місце проживання, тип випадку туберкульозу, метод підтвердження діагнозу, наявність деструкції у легенях, наявність мікобактерій туберкульозу в мокротинні. Окремо проаналізовані результати лікування.

\section{РЕЗУЛЬТАТИ Й ОБГОВОРЕННЯ}

При аналізі характеристики хворих на туберкульоз похилого та старечого віку встановлено, що серед них переважали жителі сільської місцевості: особи похилого віку - 62,0 \%, старечого віку - 79,2 \% (табл. 1). Причиною цього можливо є те, що жителі сільської місцевості - це люди важкої фрізичної праці, й також у сільській місцевості дещо обмежена своєчасна медична допомога, зокрема методи діагностики захворювань.

За типом туберкульозного процесу - вперше діагностований туберкульоз переважав як у першій, так і в другій групах хворих. Так, у першій групі серед чоловіків вперше виявлених було 87,3 \%, серед жінок - 97,0 \%. У другій групі відповідно у 95,5 і 96,2 \%. В цілому вперше діагностований туберкульоз було виявлено серед осіб похилого віку в 90,4 \%, старечого віку - в 95,8 \%.

За методом, який був вирішальним при підтвердженні діагнозу в першій групі, переважав лабораторний - виявлення мікобактерій туберкульозу

Таблиця 1. Клінічна характеристика хворих на туберкульоз легень похилого та старечого віку

\begin{tabular}{|c|c|c|c|c|c|c|c|c|c|c|c|c|c|}
\hline \multirow{3}{*}{ Розподіл за: } & \multirow{3}{*}{$\begin{array}{c}\text { Характерис- } \\
\text { тика }\end{array}$} & \multicolumn{6}{|c|}{ Перша група, похилий вік (n=104) } & \multicolumn{6}{|c|}{ Друга група, старечий вік (n=48) } \\
\hline & & \multicolumn{2}{|c|}{$\begin{array}{c}\text { чоловіки } \\
(\mathrm{n}=71)\end{array}$} & \multicolumn{2}{|c|}{$\begin{array}{l}\text { жінки } \\
(n=33)\end{array}$} & \multicolumn{2}{|c|}{ разом } & \multicolumn{2}{|c|}{$\begin{array}{c}\text { чоловіки } \\
(\mathrm{n}=22)\end{array}$} & \multicolumn{2}{|c|}{$\begin{array}{l}\text { жінки } \\
(\mathrm{n}=26)\end{array}$} & \multicolumn{2}{|c|}{ разом } \\
\hline & & абс. & $\%$ & абс. & $\%$ & абс. & $\%$ & абс. & $\%$ & абс. & $\%$ & абс. & $\%$ \\
\hline \multirow{2}{*}{$\begin{array}{l}\text { Місцем прожи- } \\
\text { вання }\end{array}$} & Місто & 27 & 38,0 & 15 & 45,5 & 40,4 & 42,0 & 5 & 22,7 & 5 & 19,2 & 10 & 20,8 \\
\hline & Село & 44 & 62,0 & 18 & 54,5 & 59,6 & 62,0 & 17 & 77,3 & 21 & 80,8 & 38 & 79,2 \\
\hline \multirow[t]{2}{*}{ Типом випадку } & $\begin{array}{l}\text { Вперше діа- } \\
\text { гностований } \\
\text { туберкульоз } \\
\text { легень }\end{array}$ & 62 & 87,3 & 32 & 97,0 & 94 & 90,4 & 21 & 95,5 & 25 & 96,2 & 46 & 95,8 \\
\hline & \begin{tabular}{|l} 
Хронічний \\
туберкульоз \\
легень
\end{tabular} & 9 & 12,7 & 1 & 3,0 & 10 & 9,6 & 1 & 4,5 & 1 & 3,8 & 2 & 4,2 \\
\hline \multirow[t]{2}{*}{$\begin{array}{l}\text { Підтвердженням } \\
\text { діагнозу, метод }\end{array}$} & $\begin{array}{l}\text { Лаборатор- } \\
\text { ний }\end{array}$ & 51 & 71,8 & 12 & 36,4 & 63 & 60,6 & 16 & 72,7 & 17 & 65,4 & 33 & 68,7 \\
\hline & $\begin{array}{l}\text { Рентгеноло- } \\
\text { гічний }\end{array}$ & 20 & 28,2 & 21 & 63,6 & 41 & 39,4 & 6 & 22,2 & 9 & 34,6 & 15 & 31,3 \\
\hline \multirow{2}{*}{$\begin{array}{l}\text { Наявністю } \\
\text { деструкції у } \\
\text { легенях }\end{array}$} & $\mathrm{Hi}$ & 38 & 53,5 & 22 & 66,7 & 60 & 57,7 & 9 & 40,9 & 13 & 50,0 & 22 & 45,8 \\
\hline & Так & 33 & 46,5 & 11 & 33,3 & 44 & 42,3 & 13 & 59,1 & 13 & 50,0 & 26 & 54,2 \\
\hline \multirow{2}{*}{$\begin{array}{l}\text { Наявністю } \\
\text { мікобактерій } \\
\text { туберкульозу в } \\
\text { мокротинні }\end{array}$} & $\mathrm{Hi}$ & 24 & 33,8 & 18 & 54,5 & 42 & 40,4 & 6 & 27,3 & 8 & 30,8 & 14 & 29,2 \\
\hline & Так & 47 & 66,2 & 15 & 45,5 & 62 & 59,6 & 16 & 72,2 & 18 & 69,2 & 34 & 70,8 \\
\hline
\end{tabular}


в мокротинні хворих. У пацієнтів першої групи цей метод переважав серед чоловіків - у 71,8 \%, другої групи серед чоловіків - у 72,7 \% і жінок - в 65,4 \%. Рентгенологічний метод був вирішальним у пацієнтів першої групи - жінок, у 63,6 \%.

При госпіталізації в осіб похилого віку деструкція легеневої тканини спостерігалась у 42,3 \%, старечого віку - в 54,2 \%. Зокрема, у пацієнтів першої групи серед чоловіків - у 46,5 \%, жінок - 33,3 \%. У другій групі відповідно в 59,1 і 50,0 \%. Наявність деструкцій у легеневій тканині пацієнтів свідчить про несвоєчасне виявлення туберкульозу.

Мікобактерії туберкульозу в мокротинні на момент госпіталізації виявлені серед осіб похилого віку в 59,6 \%, осіб старечого віку - в 70,8 \%. У першій групі серед чоловіків - у 66,2 \%, жінок - в 45,5 \%. У другій групі відповідно 72,2 і 69,2 \%. Отримані результати також підтверджують, що у таких пацієнтів туберкульоз був виявлений несвоєчасно або пізно.

Усі пацієнти в стаціонарі отримували комплексну терапію протитуберкульозними препаратами, а також патогенетичну терапію. Результати лікування хворих на туберкульоз легень похилого та старечого віку представлені у таблиці 2. Повністю одужали тільки 1 пацієнт з першої групи, з другої групи - 2 жінок $(9,1 \%)$ і 4 чоловіків $(15,4$ \%). До категорії «лікування завершене» було віднесено значно більше пацієнтів. Цей термін означає досягнення клініко-рентгенологічної стабілізації після завершення призначеного повного курсу антимікобактеріальної терапії. У першій групі серед чоловіків лікування завершене в 69,0%, серед жінок - у 84,8 \%. У другій групі відповідно - у 54,5 i $57,7 \%$.

У цілому лікувались ефективно 75,0% пацієнтів похилого віку і 68,8 \% старечого віку.

Термін «невдале лікування» - це збереження або поява бактеріовиділення, підтвердженого мазком на мікобактерії туберкульозу, з відсутністю клініко-рентгенологічної стабілізації після призначеного повного курсу антимікобактеріальної терапії понад 5 місяців. Невдалим лікуванням за клініко-рентгенологічною ознакою вважається тоді, коли бактеріовиділення відсутнє, але зберігається каверна чи деструкція із засівом, інфрільтрацією, клінічно із кровохарканням чи спонтанним пневмотораксом тощо, тобто туберкульозний процес зберігається активним чи прогресує, хоча бактеріовиділення відсутнє (МБТ-), тобто немає клінікорентгенологічної стабілізації. Невдале лікування у першій групі виявлено серед чоловіків у 18,3 \%, жінок - в 3,0%. У другій групі відповідно в 18,2 і 11,5 \%. Померли у першій групі 8 (11,3 \%) чоловіків, 4 (12,1 \%) жінок. У другій групі відповідно 4 $(18,2 \%)$ i 4 (15,4 \%).

Отже, проблема діагностики та лікування туберкульозу легень у осіб похилого та старечого віку залишається актуальною. Частіше таких пацієнтів виявляють несвоєчасно або пізно, про що свідчить великий відсоток випадків деструкції легеневої тканини і наявності мікобактерій туберкульозу в мокротинні. Переважно хворіють люди у сільській місцевості, недостатньо матеріально забезпечені. У таких осіб часто спостерігаються супутні захворювання, які можуть маскувати туберкульоз.

Таблиця 2. Результати лікування хворих на туберкульоз легень похилого та старечого віку

\begin{tabular}{|c|c|c|c|c|c|c|c|c|c|c|c|c|}
\hline \multirow{3}{*}{$\begin{array}{c}\text { Характерис- } \\
\text { тика }\end{array}$} & \multicolumn{6}{|c|}{ Перша група, похилий вік (n=104) } & \multicolumn{6}{|c|}{ Друга група, старечий вік (n=48) } \\
\hline & \multicolumn{2}{|c|}{ чоловіки $(\mathrm{n}=71)$} & \multicolumn{2}{|c|}{$\begin{array}{c}\text { жінки } \\
(n=33)\end{array}$} & \multicolumn{2}{|c|}{ разом } & \multicolumn{2}{|c|}{$\begin{array}{l}\text { чоловіки } \\
(\mathrm{n}=22)\end{array}$} & \multicolumn{2}{|c|}{$\begin{array}{l}\text { жінки } \\
(\mathrm{n}=26)\end{array}$} & \multicolumn{2}{|c|}{ разом } \\
\hline & абс. & $\%$ & абс. & $\%$ & абс. & $\%$ & абс. & $\%$ & абс. & $\%$ & абс. & $\%$ \\
\hline Вилікуваний & 1 & 1,4 & 0 & 0 & 1 & 1,0 & 2 & 9,1 & 4 & 15,4 & 6 & 12,5 \\
\hline $\begin{array}{l}\text { Лікування } \\
\text { завершене }\end{array}$ & 49 & 69,0 & 28 & 84,8 & 77 & 74,0 & 12 & 54,5 & 15 & 57,7 & 27 & 56,3 \\
\hline $\begin{array}{l}\text { Невдале } \\
\text { лікування }\end{array}$ & 13 & 18,3 & 1 & 3,0 & 14 & 13,5 & 4 & 18,2 & 3 & 11,5 & 7 & 14,5 \\
\hline Померли & 8 & 11,3 & 4 & 12,1 & 12 & 11,5 & 4 & 18,2 & 4 & 15,4 & 8 & 16,7 \\
\hline
\end{tabular}

\section{ВИСНОВКИ}

1. 3 метою своєчасного виявлення туберкульозу легень в осіб похилого та старечого віку, зокрема у жителів сільської місцевості, необхідно покращити методи діагностики цього захворювання.

2. Туберкульоз легень супроводжується деструкцією легеневої тканини серед осіб похилого віку в 42,3 \%, серед осіб старечого віку - у 54,2 \% та бактеріовиділенням - відповідно у 59,6 і 70,8 \%.

3. У цілому лікувались ефективно 75,0 \% пацієнтів похилого віку і 68,8 \% старечого, але необхідно розширити можливості комплексного лікування за рахунок нових протитуберкульозних препаратів. 


\section{СПИСОК ЛІТЕРАТУРИ}

1. Досягнення та складні питання щодо подолання туберкульозу в Україні (консолідований погляд з різних регіонів) / Л. Д. Тодоріко, В.І.Петренко, Ю.М.Валецький [та ін.] // Туберкульоз, легеневі хвороби, ВІЛ-інфрекція. 2020. - № 1(40). - C. 10-16.

2. Diagnostic chemoresistant mycobacterium tuberculosis in the Ternopil region of Ukraine / S. I. Klymnyuk, L. A. Hryshchuk, M. O. Vynnychuk [et al.] // Wiad Lek. - 2020. - Vol. 73 (5). - P. 959-962. DOI:10.36740/WLek202005122.

3. Константиновська О. С. Туберкульоз у пацієнтів похилого та старечого віку: особливості патогенезу, клініко-рентгенологічного перебігу, лікування / О. С. Константиновська // Туберкульоз, легеневі хвороби, ВІЛінсекція. - 2016. - № 3(26). - С. 86-91.

4. Бойко А. В. Туберкульоз у осіб похилого та старечого віку / А. В. Бойко // Туберкульоз, легеневі хвороби, ВІЛ-іноекція. - 2014. - № 3(19). - С. 98-99.

5. Туберкульоз в осіб похилого і старечого віку. Режим доступу: https://tdmuv.com/cd/tuberkulez/html/Rozdil16/r16.html.

\section{REFERENCES}

1.TodorikoLD, PetrenkoVI, ValetskyiYuM, ShevchenkoOS, Semianiv IO, Makoida IYa, Sakhelashvili MI, Hrischuk LA. [Achievements and difficult issues in overcoming tuberculosis in Ukraine (consolidated view from different regions)]. Tuberkuloz, lehen khvor, VIL infek. 2020;1(40): 10-6. Ukrainian.

2. Klymnyuk SI, Hryshchuk LA, Vynnychuk MO, BoikoTV, Smachylo IV, Lykhatska GV, Smachylo II. Diagnoso tic chemoresistant mycobacterium tuberculosis in the Ternopil region of Ukraine. Wiad Lek. 2020;73(5): 959-62. DOI:10.36740/WLek202005122.

3. Konstantynovska OS. [Tuberculosis for the patients of elderly and senile age:features of pathogenesis, clinicoradiological course, treatment]. Tuberkuloz, lehen khvor, VIL infek. 2020;1(40): 10-6. Ukrainian.

4. Boyko AV [Tuberculosis in the elderly and senile age]. Tuberkuloz, lehen khvor, VIL infek. 2020;1(40): 10-6. Ukrainian.

5. Tuberculosis in the elderly and senile age. Available from: https://tdmuv.com/cd/tuberkulez/html/Rozdil16/r16. html. Ukrainian.
6. Piergallini T. J. Tuberculosis in the elderly: Why inflammation matters / Tucker J. Piergallini, Joanne Turner // Experimental Gerontology. - 2018. - No. 105. - P. 32-39.

7. Functional hepatic disorders in the patients with first diagnosed pulmonary tuberculosis / L. Hryshchuk, O. Okug sok, T. Boiko [et al.] // Georgian Medical News. - 2017. No. 10 (271). - P. 43-55.

8. Tuberculosis in the elderly in Germany / B. Hauer, B. Brodhun, D. Altmann [et al.] // European Respiratory Journal. - 2011. - Vol. 38. - P. 467-470. DOI: 10.1183/09031936.00199910.

9. Diagnosing pulmonary tuberculosis in the elderly / Michael J. Symes, Ben Probyn, Cyrus Daneshvar, Lilanganee Telisinghe // Current Geriatrics Reports. - 2020. - Vol. 9. - P. 30-39.

10. Time to diagnosis of tuberculosis is greater in older patients: a retrospective cohort review / Aula Abbara, Simon M. Collin, Onn M. Kon [et al.] // ERJ Open Res. - 2019. No. 4; 5 (4). - P. 2028-2018. DOI: 10.1183/23120541.002282018. eCollection 2019 Oct.

6. Piergallini TJ, Turner J. Tuberculosis in the elderly: Why inflammation matters. Experimental Gerontology. 2018;105: 32-9.

7. Hryshchuk L, Okusok O, Boiko T, Lykhatska H, Radetska L. Functional hepatic disorders in the patients with first diagnosed pulmonary tuberculosis. Georgian Medical News. 2017;10(271): 43-55.

8. Hauer Brodhun B, Altmann D, Fiebig L, Loddene kemper R, Haas W. Tuberculosis in the elderly in Germany. European Respiratory Journal. 2011;38: 46770. DOI: $10.1183 / 09031936.00199910$.

9. Michael J Symes, Ben Probyn, Cyrus Daneshvar, Lilanganee Telisinghe. Diagnosing pulmonary tuberculosis in the elderly. Current Geriatrics Reports. 2020;9: 30-9.

10. Aula Abbara, Simon M Collin, Onn M Kon, Kevin Buell, Adam Sullivan, Jessica Barrett, Tumena Corrah et al. Time to diagnosis of tuberculosis is greater in older patients: a retrospective cohort review. ERJ Open Res. 2019;4;5(4): 2018-28. DOI: 10.1183/23120541.00228-2018. eCollection 2019 Oct. 